\title{
Study on the Current Situation of Transnational Merger and Acquisition of Private enterprises in China
}

\author{
Song Xingang \\ Business School, \\ Huaiyin Institute of Technology, \\ Huaian, P.R. China, 223001 \\ E-mail: hyjhys@163.com
}

\begin{abstract}
Transnational mergers and acquisitions are becoming an important form of the "go out" strategy of Chinese enterprises. In the past few years, Chinese private enterprises have developed rapidly in cross-border mergers and acquisitions and have achieved greater success. The thesis aims to clarify the real situation of transnational mergers and acquisitions of private enterprises in China. This paper analyzes the basic situation of China's private enterprises in cross-border M\&A from two aspects: development status and existing problems. It is concluded from the study that in general, private enterprises in China still have a long way to go in cross-border $m \& a$ and are still in the primary stage of development.
\end{abstract}

Keywords-Private enterprises; Transnational mergers and acquisitions; Status quo; Problems

\section{THE STATUS QUO OF CROSS - BORDER M \& A OF CHINESE PRIVATE ENTERPRISES}

International financial data provider Dealogic data show that in 2015, Chinese enterprises implemented a total of 579 foreign investment $M$ \& A projects, involving 62 countries (regions) and 18 major categories of industry, the actual transaction amounted to $\$ 54$ billion 440 million. Since 2016, crossborder mergers and acquisitions of Chinese enterprises have entered the fast lane. According to Thomson Reuters, based on slowing and worries about health of banking financial industry's economic growth, the first three quarters of 2016, the global M \& A transactions fell 22\%, and fell to the lowest level in three years, but Chinese enterprise has launched 521 overseas acquisitions, the actual transaction amount of $\$ 67$ billion 440 million, an increase of $68 \%$. At the same time, far more than the 2015 annual amount of mergers and acquisitions. Not only that, the proportion of Chinese enterprises in the global $\mathrm{M}$ $\&$ a market increased to $30 \%$, and China surpassed the United States for the first time, becoming the largest country to buy foreign capital.

A. The growth rate of China's foreign investment continues to be higher than that of the world

In recent years, the Chinese government has been actively promoting the economic development of the "Belt and Road" and continuously perfected the "going out" policy system. The foreign investment and cooperation continued to maintain rapid growth. Figure 1 shows that from 2002 to 2015, China's outward direct investment grew at an average annual rate of $35.9 \%$, maintaining rapid growth for 13 consecutive years. In 2015, China made a historic breakthrough in its foreign direct investment. For the first time, direct foreign direct traffic ranked the second in the world after the United States, reaching 145.67 billion U.S. dollars, up $18.3 \%$ from the same period of last year and higher than the growth rate of $6.5 \%$ in the world.

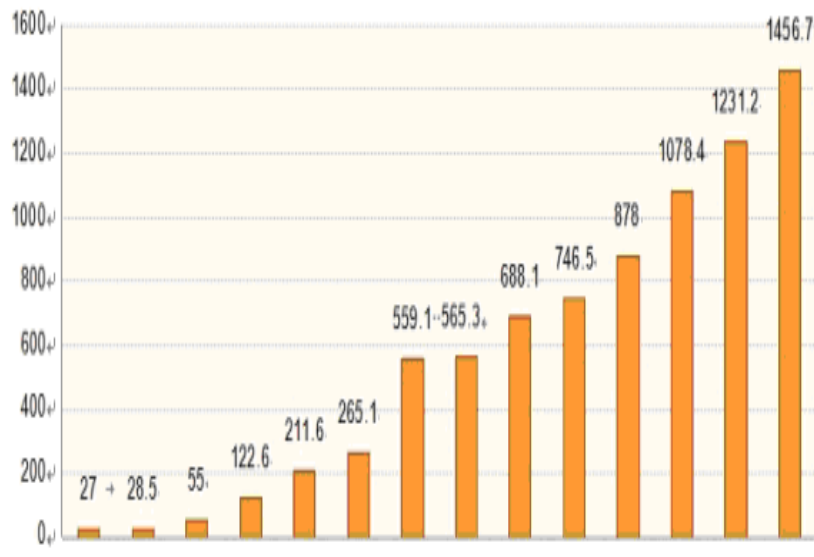

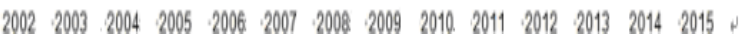

Fig. 1 China's Outward FDI in 2002-2015 (Billions of U.S. dollars)

Source: China Statistical Yearbook of Foreign Direct Investmen

\section{B. The proportion of China's foreign direct investment flows} continues to increase worldwide

During the 12th FYP period, the global share of China's foreign direct investment (FDI) flows has been increasing year by year. The global total figure in 2011-2015 was 4.8\%, 6.7\%, $8.2 \%, 9.3 \%$ and $9.9 \%$ respectively, as shown in Figure 2. Cross-border M \& A is becoming the main way for Chinese enterprises to invest and cooperate with foreign countries. "Going Global" has become an important way for China's economic restructuring and economic cooperation and mutual benefit and win-win cooperation. It has accelerated the pace of China's integration into the world economy [2] [4]. 


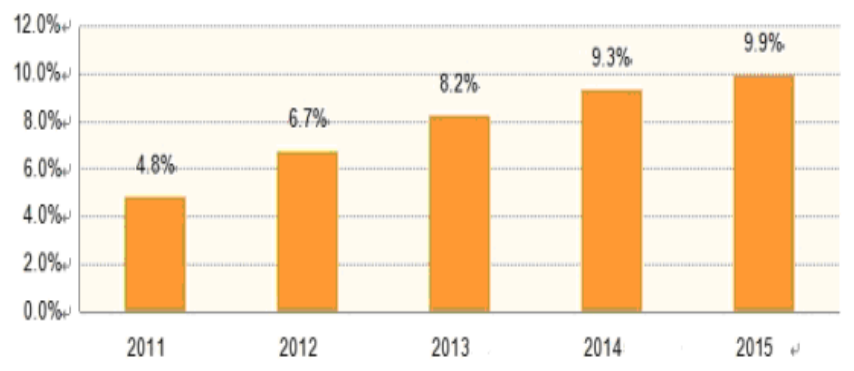

Fig. 2 China's foreign direct investment flows accounted for the global proportion during the period of 12th Five-Year

Data sources: Ministry of Commerce "statistical bulletin of China's foreign direct investment in 2015"; United Nations Conference on Trade and development "World Investment Report 2016"

\section{China's foreign investment began to appear net outflow of capital phenomenon}

In recent years, although the overall recovery of the world economy is weak and the growth rate is slowing down, China's foreign direct investment and foreign investment continue to maintain a good momentum of development. In 2015, China's foreign direct investment and China's actual use of foreign investment amounted to $\$ 145$ billion 670 million and $\$ 135$ billion 600 million respectively. Net outflow of capital reached US $\$ 10$ billion 70 million, and net export of capital was realized under direct investment. China began to enter the net capital exporting country.

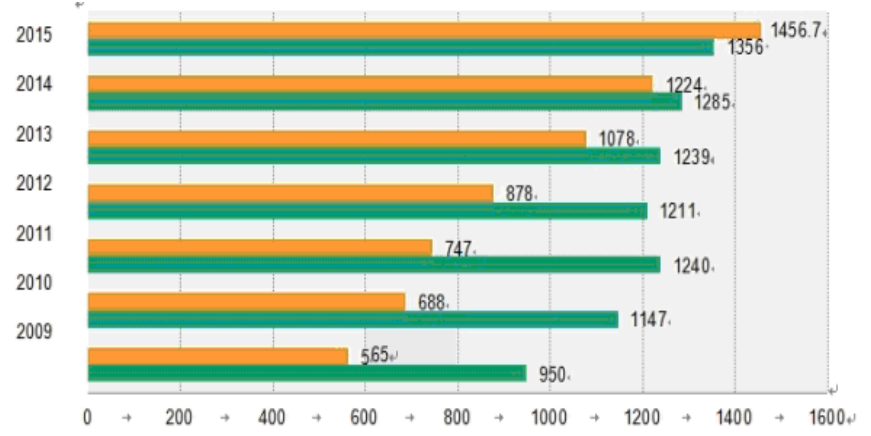

Fig. 3 Comparison of China's Two-way Direct Investment in 2009-2015 (100 million U.S. dollars)

Source: China Statistical Yearbook of Foreign Direct Investment

\section{The gap between the stock of China's foreign direct in- vestment and the developed countries narrows}

In 2015, China's foreign direct investment stock stood at 1.09786 trillion U.S. dollars, accounting for $4.4 \%$ of the global stock of overseas investment, an increase of $1 \%$ from the previous year and continuing to be the eighth in the world [1]. In 2015, the stock of China's OFDI was equivalent to $59.5 \%$ and $70.1 \%$ of the current stock in the United States and Germany respectively, further narrowing the gap with the stock of developed countries such as the United States and Germany.

\section{E. The distribution of cross-border mergers and acquisitions in China is basically in line with the trend of global capital flows}

Foreign direct investment is divided into cross-border mergers and acquisitions investment and Greenfield investment in two modes. In terms of cross-border $M \& A$ investment, the global industry with the largest cross-border M \& A investment in 2015 was manufacturing, with the $M$ \& A volume reaching 388 billion U.S. dollars, accounting for $53.7 \%$ of the total, up $105.3 \%$ over the same period of last year. The M \& A in service industry was 302 billion U.S. dollars Representing an increase of $45.9 \%$ over the same period of last year. The acquisition of primary commodities sector amounted to US \$ 32 billion, accounting for $4.4 \%$ of the total, down $11.1 \%$ over the same period of last year. In 2015, the largest industry of China's M \& A investment was manufacturing, with cross-border M \& A volume reaching 13.72 billion U.S. dollars, accounting for $25.2 \%$ of the total, up $13.4 \%$ over the same period of last year.

\section{F. China's cross-border mergers and acquisitions growth rate declined}

China cross-border mergers and acquisitions 579, the actual total transaction 54.44 billion US dollars, down 4.3\%. According to the World Investment Report 2016, the share of crossborder mergers and acquisitions in developed economies in 2015 accounted for $67 \%$ of the total, up nearly $8 \%$ over the same period last year.

\section{G. Diversified investment enterprises, private enterprises be- come the mainstream of investment.}

In recent years, with the enhancement of economic strength, the pace of China's private enterprises to participate in crossborder mergers and acquisitions began to accelerate significantly. Statistics show that in 2015 , the number of overseas mergers and acquisitions of non state owned enterprises exceeded the number of state-owned enterprises. By the end of 2015, China's foreign direct investment in non-financial sectors stood at us $\$ 938.2$ billion. Among them, state-owned enterprises accounted for 50.4 per cent, and the share of non-financial sectors continued to fall. Non-state enterprises accounted for 49.6 per cent, an increase of 3.2 percentage points over the previous year, which was roughly equal to the external investment of state-owned enterprises and diversified development of investment subject structure.

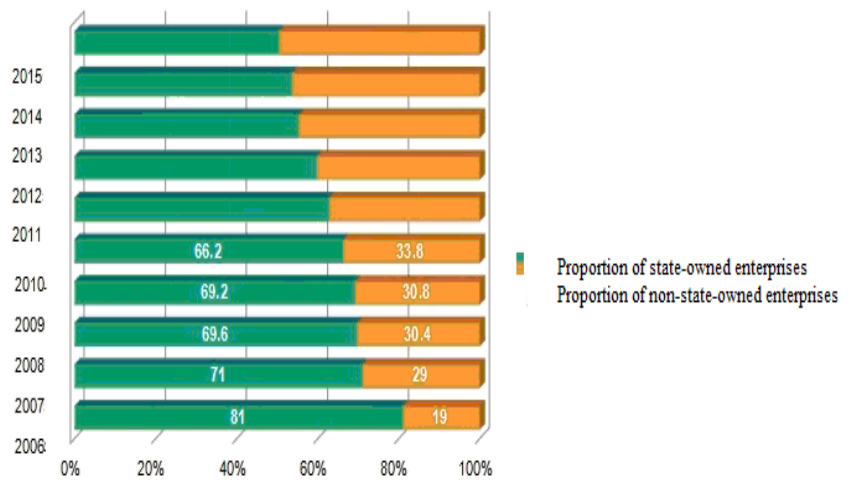

Fig. 4 China's Outward FDI Structure in 2015

Source: Ministry of Commerce, "Statistical Communique on China's Outward FDI in 2015"

As of the end of 2015, there were 20,200 OFDI enterprises in China, with diversified types of investment enterprises, including $67.4 \%, 9.3 \%, 7.7 \%$ and $0.9 \%$ respectively for limited 
liability companies, private companies, joint stock limited companies, self-employed and collective enterprises And $0.4 \%$. According to the definition of private enterprise in this article, the removal of state-owned enterprises and foreign-funded enterprises (including Hong Kong, Macao and Taiwan investment enterprises), private enterprises accounted for nearly $86 \%$ of China's foreign direct investment enterprises.

\section{THE MULTINATIONAL MERGERS AND ACQUISITIONS OF PRIVATE ENTERPRISES SWOT ANALYSIS}

\section{A. The advantages of private enterprises overseas mergers and acquisitions}

1) Property rights are clear. Chinese private-owned enterprises have strong people's color, clear property rights, overseas acquisitions and enterprises are more likely to be accepted by foreign countries.

2) Rrapid decision-making. The decision-making power of private enterprises is relatively concentrated, making it easy to make decisions in mergers and acquisitions.

3) Rational and pragmatic. The lack of financing channels for private enterprises, more in overseas mergers and acquisitions to use their own funds, financing costs are relatively high. Therefore, private enterprises are more rational and pragmatic and more stable in overseas $\mathrm{M} \& \mathrm{~A}$.

\section{B. Private enterprises overseas mergers and acquisitions disadvantage}

1) Lack of financing channels. At present, how to obtain effective financing is still the short board of overseas M \& A by private enterprises. Improving the financing ability of private enterprises is an important measure to enhance their $\mathbf{M}$ \& A strength.

2) Lack of overseas $M \& A$ experience. As private enterprises in China go abroad for a short time, compared with state-owned enterprises, they are small in scale and have fewer opportunities to participate in mergers and acquisitions. They lack experience in cross-border $\mathrm{M} \& \mathrm{~A}$ and their operating risks are relatively greater.

3) Lack of management experience. Compared with foreign advanced management techniques, there is still a long way to go to manage the private enterprises in our country. Due to the relative lack of management experience, non-state owned enterprises in our country not only can not manage collaboratively after the $\mathrm{M} \& \mathrm{~A}$, but also often leads to the failure of the merger due to the brain drain and employee conflict in the later period.

\section{Private enterprises overseas mergers and acquisitions opportunities}

1) The support of national policy. The Ministry of Commerce clearly put forward the strategy of "going out" vigorously in 2010 and encouraged enterprises to go out and participate in international economic cooperation and competition. ${ }^{[7]}$ This from the strategic level for enterprises to go out and cross-border M \& A provide policy support. At the same time, the government also promulgated the corresponding policy support in the fields of finance, insurance and foreign exchange, and vigorously advocated that financial institutions should provide capital and credit support for enterprises to go out. In the meantime, MOFCOM also provided investment guides for 162 countries and regions for its "going global", established bilateral and multilateral cooperation among countries, improved communication and exchanges between governments, and provided a favorable international environment for cross-border $\mathrm{M} \&$ As of enterprises And market opportunities.

2) The development of science and technology has provided new opportunities for private enterprises. Compared with multinational corporations, China's non-state-owned enterprises in the "core technology" is not dominant. Without a major breakthrough in core technology or in independent research and development, many private-sector companies in the pressures of foreign capital and competitive markets have the risk of collapsing. Faced with such a harsh environment, the choice of Chinese private enterprises to go overseas for mergers and acquisitions is undoubtedly the best choice for obtaining the core technology of the enterprise. Acquiring advanced technologies through mergers and acquisitions and innovating on this basis have provided new opportunities for the growth and development of private-owned enterprises in China.

\section{Private enterprises overseas mergers and acquisitions challenges}

In recent years, with the rapid economic development, the pace of overseas mergers and acquisitions by Chinese enterprises has started to accelerate. However, Western countries headed by the United States still have the environment to curb China's development mentality, disseminate the "China threat theory" and "the collapse of China", etc., and continuously worsen the international $\mathrm{M} \& \mathrm{~A}$ and investment environment for Chinese enterprises. Although Chinese enterprises have continuously improved their national image and reputation through various efforts over the years, some countries still raise the international mergers and acquisitions of Chinese enterprises to the height of the national security and domination of the world and continue the policy of containing China's economic development.

\section{THE PROBLEMS OF CROSS-BORDER MERGERS AND ACQUISITIONS OF PRIVATE ENTERPRISES}

\section{A. Lack of overall strategic planning}

M \& A strategy refers to the purpose and approach of M \& A. Chinese enterprises generally lack overall strategic planning in cross-border mergers and acquisitions. The fundamental value of $\mathrm{M} \& \mathrm{~A}$ is to acquire core resources of mergers and acquisitions, cultivate and enhance core competitiveness and sustainable development ability. In the understanding of the activities of transnational mergers and acquisitions, private enterprises in our country there are still some misunderstanding, they usually put the internationalization of enterprises as the goal rather than the means, for them, cross-border mergers and acquisitions to achieve the enterprise internationalization, but 
ignore the fundamental purpose of cross-border mergers and acquisitions is to cultivate and improve the core competitiveness of enterprises [6].

\section{B. Ignore the collaborative management after mergers and acquisitions}

M \& A itself does not create value, and the value of $M$ \& A of private enterprises comes from the integration of resources after the merger of two enterprises. However, China's private enterprises often ignore this point in the practice of crossborder mergers and acquisitions. Many private enterprises believe that the signing of $M \& A$ agreements means the success of mergers and acquisitions, or that cross-border mergers and acquisitions integration is considered after the signing of merger agreements, all of which lead to the performance of crossborder mergers and acquisitions of private enterprises in China is generally not high. At the same time, most private enterprises in China only focus on the integration of real capital, ignoring the integration of culture and human resources. The integration of core competence will determine the success or failure of cross-border mergers and acquisitions to some extent [9].

\section{The choice of the target enterprise error}

At present, cross-border mergers and acquisitions in the world show a new trend of development, that is, enterprises to improve the core competitiveness as the goal, to achieve their own advantages in the global expansion. Therefore, the choice of $\mathrm{M} \& \mathrm{~A}$ enterprises mainly focuses on the elements of resources and core competitiveness of the acquired enterprises, as well as the matching of strategic, cultural and organizational aspects, while not just focusing on the scale growth of enterprises and saving the cost of acquisitions.[10] However, the short-term interests of private enterprises in China tend to focus on cross-border mergers and acquisitions, attraction, blind decision for immediate preferential policies or a particular aspect of the enterprise interests, the choice of the enterprise's core competitive ability and improve effect of target enterprise. The results of the enterprise mergers and acquisitions are for the tired.

\section{CONCLUSION}

With the expansion of transnational business activities, more and more private enterprises in China participate in crossborder M \& a activities. China's private enterprises crossborder mergers and acquisitions activities have emerged many successful cases, but also produced some failure cases. The main lessons of transnational failure of private enterprises in China are the lack of overall strategic planning, the neglect of collaborative management after transnational mergers and acquisitions, and the selection errors of target enterprises.

\section{REFERENCE}

[1] Ministry of Commerce, "Statistical Communique on China's Outward FDI in 2015".

[2] Xie Kang, Yu Lei. "Bringing in" and" going out" of Chinese foreign investment strategy. The world economy research, 2003 (6).

[3] Chen Aiping. Characteristics, problems and suggestions of overseas mergers and acquisitions of Chinese private enterprises $[\mathrm{J}]$. foreign trade practice. 2011 (12)

[4] Zhao Wei. The internationalization of private enterprises in the "12th Five-Year plan" period and Countermeasures -- Taking Zhejiang as an example to analyze [J]. learning and practice. 2010 (12).

[5] Zhou Min. Private enterprises overseas mergers and acquisitions of the advantages and disadvantages of analytical [J]. people's Forum (26) 2010.

[6] Zhang Jianhong, Wei Xin Jiang, Heike Albers. Factor analysis on the success or failure of overseas acquisition of Chinese enterprises [J]. management world. 2010 (03).

[7] Wang Linsheng. Transnational M \& A, China's foreign investment policy, [J]. world economy, 2011 (07).

[8] Tu wanchun, Chen Fengxian. Chinese foreign direct investment stage of empirical analysis. Journal of Industrial and Commercial University of Chongqing,2006 (1).

[9] Yang jianquan, Yang Xiaowu, Wang Jie. China's Foreign Direct Investment: An Empirical Study of IDP test and trend analysis. International trade issues, 2006(8).

[10] Liang Jun, Xie Kang. "Chinese two-way investment structure: stage" test and development trend, world economy research, 2008(1). 